\title{
Liter per Mole per Minute
}

National Cancer Institute

\section{Source}

National Cancer Institute. Liter per Mole per Minute. NCI Thesaurus. Code C85683.

Liters per mole per minute. 